\title{
Pengamanan Citra Dengan Kombinasi Modified Serpent Dan IWT Dengan Modified Logistic Chaotic Map
}

\author{
Allwin M.Simarmata ${ }^{1}$, Kelvin Lysander ${ }^{2}$, Denniel Lusandy ${ }^{3}$, Iswandi ${ }^{4}$ \\ Universitas Prima Indonesia; Jl. Sekip simp. Sikambing, 061-4578890 \\ Jurusan Teknik Informatika, FTIK Universitas Prima Indonesia, Medan \\ e-mail: ${ }^{1}$ allwinsimarmata@ unprimdn.ac.id, ${ }^{2}$ kelvinlysander25@gmail.com, \\ 3dlusandy0915@gmail.com, ${ }^{4}$ iswandizhang98@gmail.com
}

\begin{abstract}
Abstrak
Algoritma kriptografi dapat digunakan untuk mengamankan citra. Salah satu algoritma kriptografi yang dapat digunakan untuk mengenkripsi citra adalah algoritma Serpent. Namun, algoritma Serpent memerlukan proses enkripsi dan dekripsi yang lama. Untuk mengurangi waktu yang diperlukan dalam proses enkripsi dekripsi, dilakukan modifikasi pada algoritma Serpent dengan memanfaatkan sistem chaos dan cyclic group. Dengan metode ini membuat waktu proses menjadi lebih cepat dan jumlah iterasi yang dibutuhkan berkurang menjadi 10 putaran serta meningkatkan kompleksitas algoritma. Selain itu, pengenkripsian saja tidaklah cukup karena akan menimbulkan kecurigaan sehingga informasi akan rentan dicuri. Maka diperlukan teknik steganografi seperti metode Integer Wavelet Transform (IWT). Metode ini muncul untuk mengatasi kelemahan terhadap robustness dan imperceptibility yang ada pada Least Significant Bit (LSB). Berdasarkan hasil pengujian yang dilakukan, diperoleh informasi bahwa perubahan nilai kunci dan parameter yang digunakan pada Modified Serpent tidak berpengaruh terhadap kecepatan waktu enkripsi dan dekripsi, waktu dekripsi jauh lebih cepat daripada waktu enkripsi dan semua nilai parameter $x 0, y 0, z 0, \alpha, \beta, \gamma$ dari algoritma Modified Logistic Chaotic Map yang diberi nilai sama akan menghasilkan nilai MSE dan PSNR yang lebih baik dibandingkan dengan nilai parameter lainnya yang berubah atau tidak sama.
\end{abstract}

Kata kunci-citra, kriptografi, metode Serpent, steganografi, Integer Wavelet Transform

\begin{abstract}
Cryptographic algorithms can be used to secure images. One of the cryptographic algorithms that can be used to encrypt images is the Serpent algorithm. However, the Serpent algorithm requires a long encryption and decryption process. To reduce the time required in the encryption decryption process, modifications were made to the Serpent algorithm by utilizing the chaos system and cyclic group. This method makes processing time faster and the number of iterations required is reduced to 10 rounds and increases the complexity of the algorithm. In addition, encryption alone is not enough because it will raise suspicions so that the information will be vulnerable to being stolen. So we need a steganography technique such as the Integer Wavelet Transform (IWT) method. This method appears to overcome the weaknesses of robustness and imperceptibility that exist in Least Significant Bit (LSB). Based on the results of the tests carried out, information is obtained that changes in the key values and parameters used in Modified Serpent have no effect on the speed of encryption and decryption time, the decryption time is much faster than the encryption time and all parameter values $x 0, y 0, z 0,$, , of the Modified Logistic Chaotic Map algorithm which is given the same value will produce better MSE and PSNR values compared to other parameter values that change or are not the same.
\end{abstract}

Keywords - image, cryptography, Serpent method, steganography, Integer Wavelet Transform 


\section{PENDAHULUAN}

Citra memuat nilai informasi yang penting dan rahasia, sehingga perlu dienkripsi agar hanya pihak berwenang yang memiliki kunci yang dapat mendekripsinya. Salah satu algoritma kriptografi yang dapat digunakan untuk mengenkripsi citra adalah algoritma Serpent. Algoritma ini menggunakan teknik cipher blok dengan kunci simetris. Proses enkripsi ini dimulai dengan melakukan permutasi inisial lalu diikuti sebanyak 32 putaran pada transformasi subsitusi dan kemudian permutasi akhir [1]. Algoritma ini memiliki tingkat keamanan yang sebanding dengan Advanced Encryption Standard (AES) namun lemah dari segi kecepatan dikarenakan lebih banyak jumlah putaran yang dibutuhkan [2]. Untuk mengurangi waktu yang diperlukan dalam proses enkripsi dekripsi, dilakukan modifikasi pada algoritma Serpent dengan memanfaatkan sistem chaos dan cyclic group. Modifikasi ini mengubah proses transformasi substitusi byte (DES S-box) menjadi list bilangan prima 257 yang memiliki 128 generator untuk digunakan sebagai kunci di setiap putarannya. Dengan metode ini membuat waktu proses menjadi lebih cepat dan jumlah iterasi yang dibutuhkan berkurang menjadi 10 putaran serta meningkatkan kompleksitas algoritma [2].

Namun, pengenkripsian saja tidaklah cukup karena akan menimbulkan kecurigaan sehingga informasi akan rentan dicuri. Maka diperlukan teknik steganografi untuk menyembunyikan pesan atau informasi ke dalam suatu media tertentu agar pihak lain tidak mengetahui keberadaan pesan tersebut [3]. Metode steganografi yang digunakan adalah Integer Wavelet Transform (IWT) yang merupakan teknik transformasi domain. Metode ini muncul untuk mengatasi kelemahan terhadap robustness dan imperceptibility yang ada pada Least Significant Bit (LSB). Kemudian digunakan IWT karena hasilnya tampak mirip dengan citra asli, tetapi dengan ukuran yang lebih kecil. Metode ini menciptakan noise yang lebih sedikit setelah proses penyisipan dikarenakan bahwa transformasi tersebut memberikan toleransi yang tinggi terhadap noise citra [4].

Pada proses penyisipan dengan metode IWT, perlu ditentukan posisi bit dan piksel pada cover image yang akan disisipkan sebuah pesan. Untuk menentukan posisi tersebut, maka digunakanlah fungsi chaos. Karakteristik chaos adalah sensitivitas terhadap kondisi awal, berkelakuan acak, dan tidak memiliki periode berulang.Logistic map merupakan salah satu fungsi chaos yang banyak digunakan dalam teknik penyisipan data karena sederhana dan sangat cepat tetapi fungsi ini sendiri memiliki ruang kunci yang kecil [5]. Permasalahan ruang kunci merupakan faktor penting dalam metode keamanan [6]. Untuk meningkatkan keamanan, dilakukan sebuah modifikasi pada logistic map untuk meningkatkan ruang kunci dengan menambahkan tiga variabel baru berupa $\alpha, \beta$, dan $\gamma$ sebagai parameter baru. Variabel tersebut sangat bergantung dengan variabel lainnya sehingga nilai yang dimasukkan berbeda sedikit saja, maka akan menghasilkan perubahan yang signifikan [7].

Penelitian sejenis yang pernah dilakukan sebelumnya seperti "Kombinasi Steganografi Bit Matching Dan Kriptografi Playfair Cipher, Hill Cipher Dan Blowfish" [8]. Pada penelitian ini, dilakukan pengujian untuk melihat waktu yang dipakai untuk melakukan kombinasi steganografi bit matching serta mengkombinasikan beberapa metode kriptografi seperti playfair, hill cipher dan blowfish. Hasilnya ialah untuk citra hitam putih diperoleh waktu rata-rata embedding 28.275 detik ekstraksi 27.843 detik dan untuk citra berwarna waktu rata-rata embedding 13.0208 detik dan ekstraksi 12,7986 detik.

Penelitian lainnya berjudul "Implementasi Algoritma Enkripsi Citra Digital Berbasis Chaos Menggunakan Fungsi Komposisi Logistic Dan Gauss Iterated Map" [9]. Hasil uji PSNR terhadap semua citra asli dengan citra hasil dekripsi menujukkan bahwa nilai PSNR tak hingga, dan MSE bernilai nol, hal ini menunjukan bahwa citra asli dengan citra hasil dekripsi sama atau

Allwin, et., al [Pengamanan Citra Dengan Kombinasi Modified Serpent Dan IWT Dengan Modified Logistic Chaotic Map] 
tidak berubah. Waktu proses enkripsi dan dekripsi citra grayscale relatif lebih cepat daripada citra warna. Waktu proses enkripsi dan dekripsi juga bergantung pada ukuran pixel dari citra.

Penelitian lainnya "Proses Pengamanan Data Menggunakan Kombinasi Metode Kriptografi Data Encryption Standard dan Steganografi End Of File" [10]. Berdasarkan hasil pengujian yang dilakukan pesanrahasia berhasil dienkripsi dengan menggunakan panjang kunci 56 bit kemudian disisipkan pada citra digital menggunakanEOF dan memiliki hasil pengujian bahwa pesan yang disisipan dapat diambil kembali untuk dapat dilakukan proses dekripsi.

\section{METODE PENELITIAN}

Prosedur kerja dari proses penyisipan mencakup proses enkripsi pesan dan proses embedding, yang dapat digambarkan dalam bentuk flowchart diagram seperti terlihat pada gambar 1.

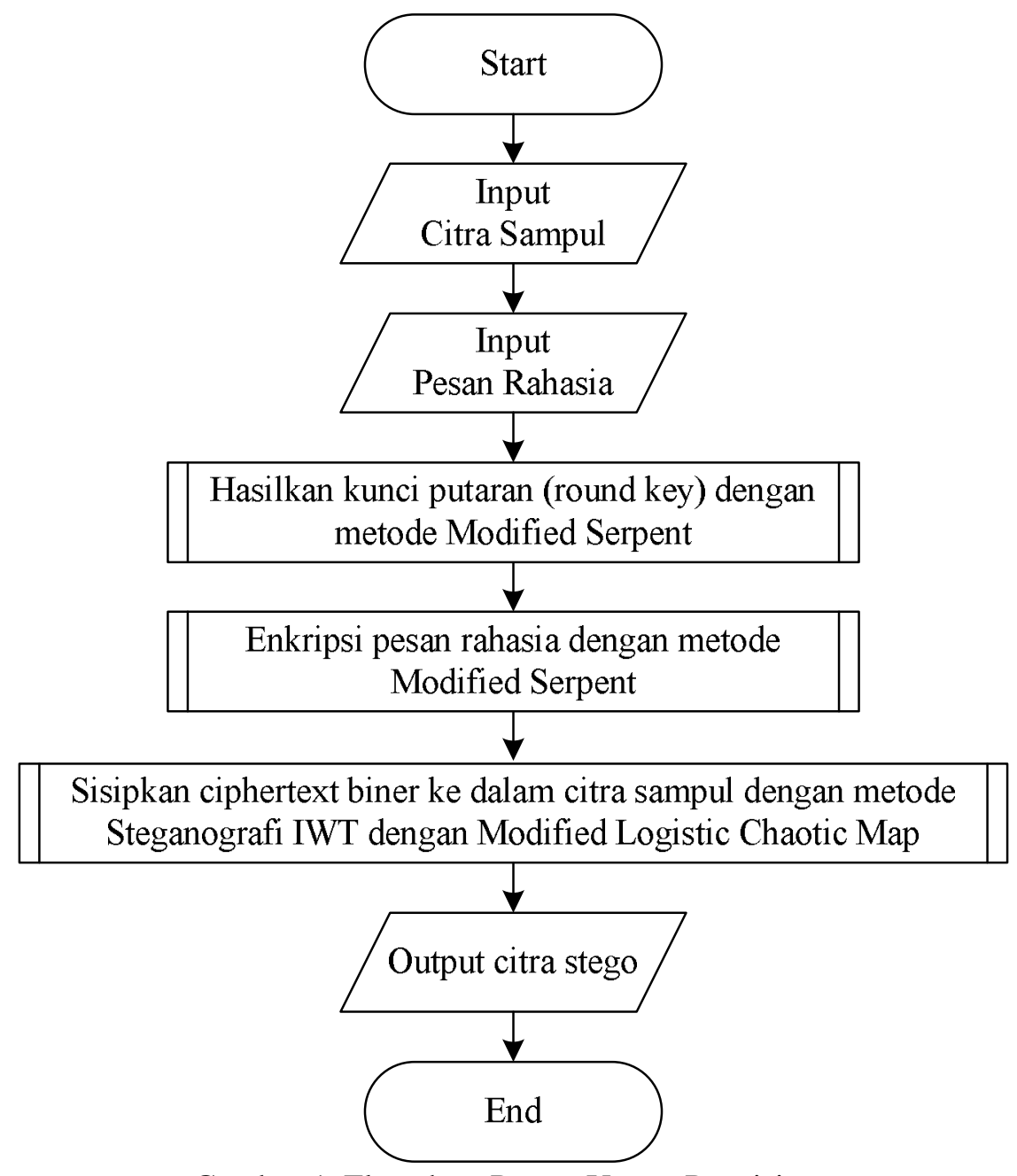

Gambar 1. Flowchart Proses Utama Penyisipan

Secara garis besar, proses ekstraksi dapat dilihat pada gambar 2. 


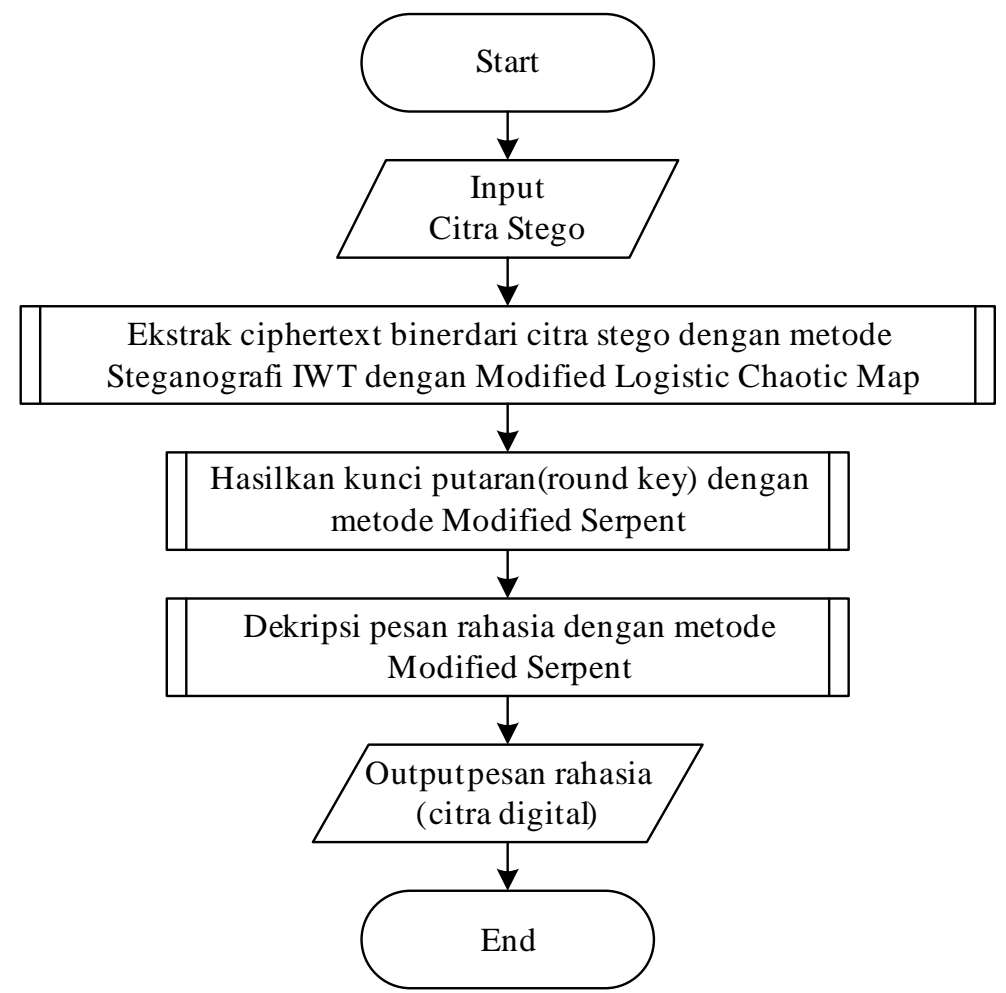

Gambar 2. Flowchart Proses Ekstraksi

\section{HASIL DAN PEMBAHASAN}

\subsection{Hasil}

Pada bagian ini dijelaskan hasil akhir mengenai perangkat lunak. Untuk menggunakan perangkat lunak ini, jalankan file "Modified Serpent.exe", maka akan ditampilkan halaman utama dari program seperti terlihat pada Gambar 3.

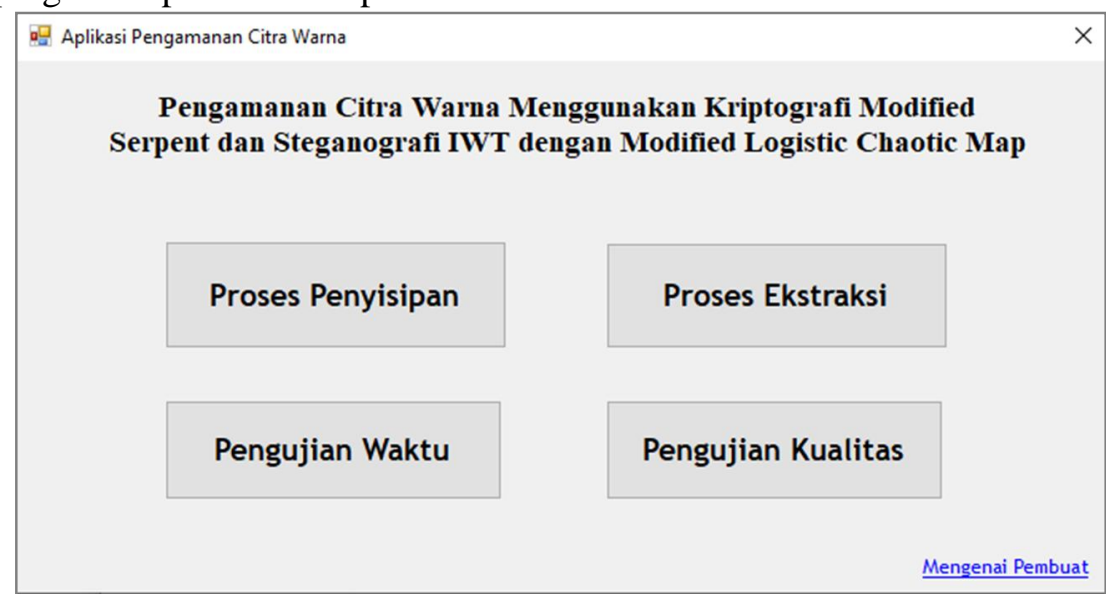

\section{Gambar 3. Tampilan Form Utama}

Proses enkripsi dengan menggunakan metode Modified Serpent ini dapat dilakukan dengan mengklik Button 'Proses Penyisipan' pada form Utama sehingga sistem akan menampilkan form Proses Enkripsi seperti terlihat pada Gambar 4. berikut:

Allwin, et., al [Pengamanan Citra Dengan Kombinasi Modified Serpent Dan IWT Dengan Modified Logistic 


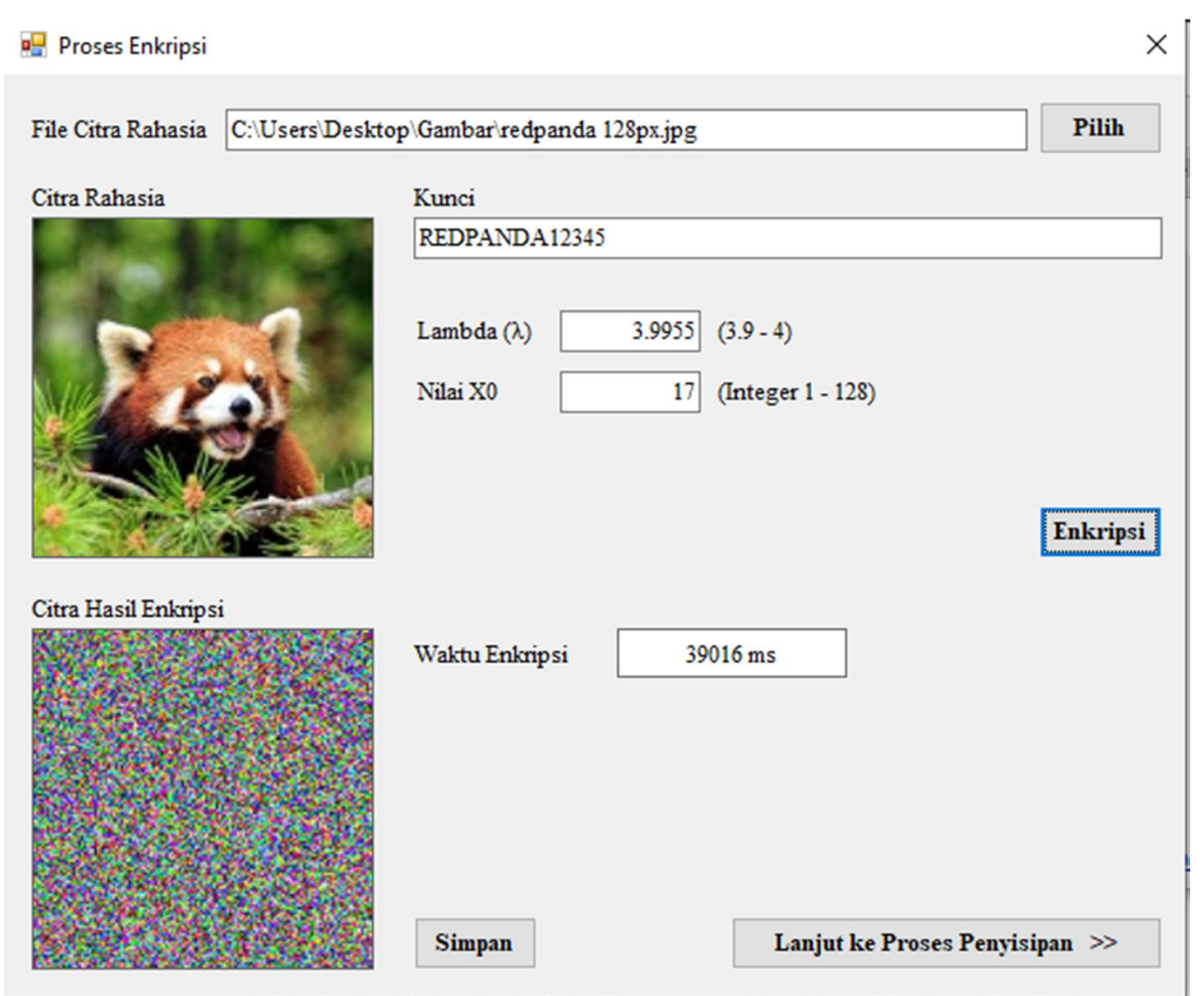

Gambar 4. Tampilan Form Proses Enkripsi Setelah Citra di Enkripsi

Proses penyisipan dengan menggunakan metode Modified Logistic Chaotic Map dan IWTini dapat dilakukan setelah proses enkripsi dilakukan setelah itu klik tombol'Lanjut ke Proses Penyisipan' pada form Proses Enkripsi sehingga sistem akan menampilkan form Proses Penyisipan seperti terlihat pada Gambar 5. berikut: 


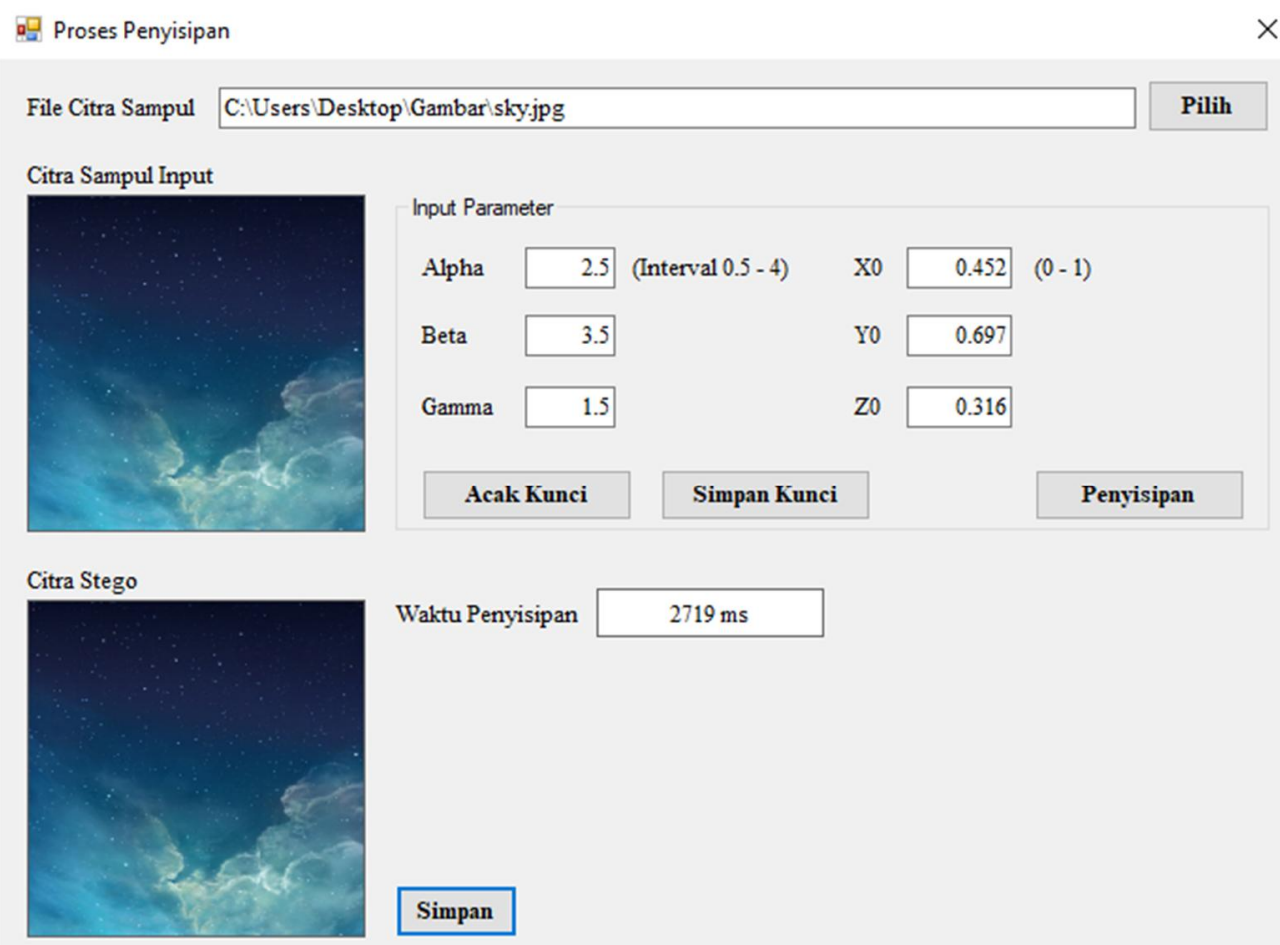

Gambar 5. Tampilan Form Proses Penyisipan Setelah Citra Pesan Disisip

Proses ekstraksi dengan menggunakan metode Modified Logistic Chaotic Map dan IWTini dapat dilakukan dengan mengklik Button 'Proses Ekstraksi' pada form Utama sehingga sistem akan menampilkan form Proses Ekstraksi seperti terlihat pada Gambar 6. berikut:

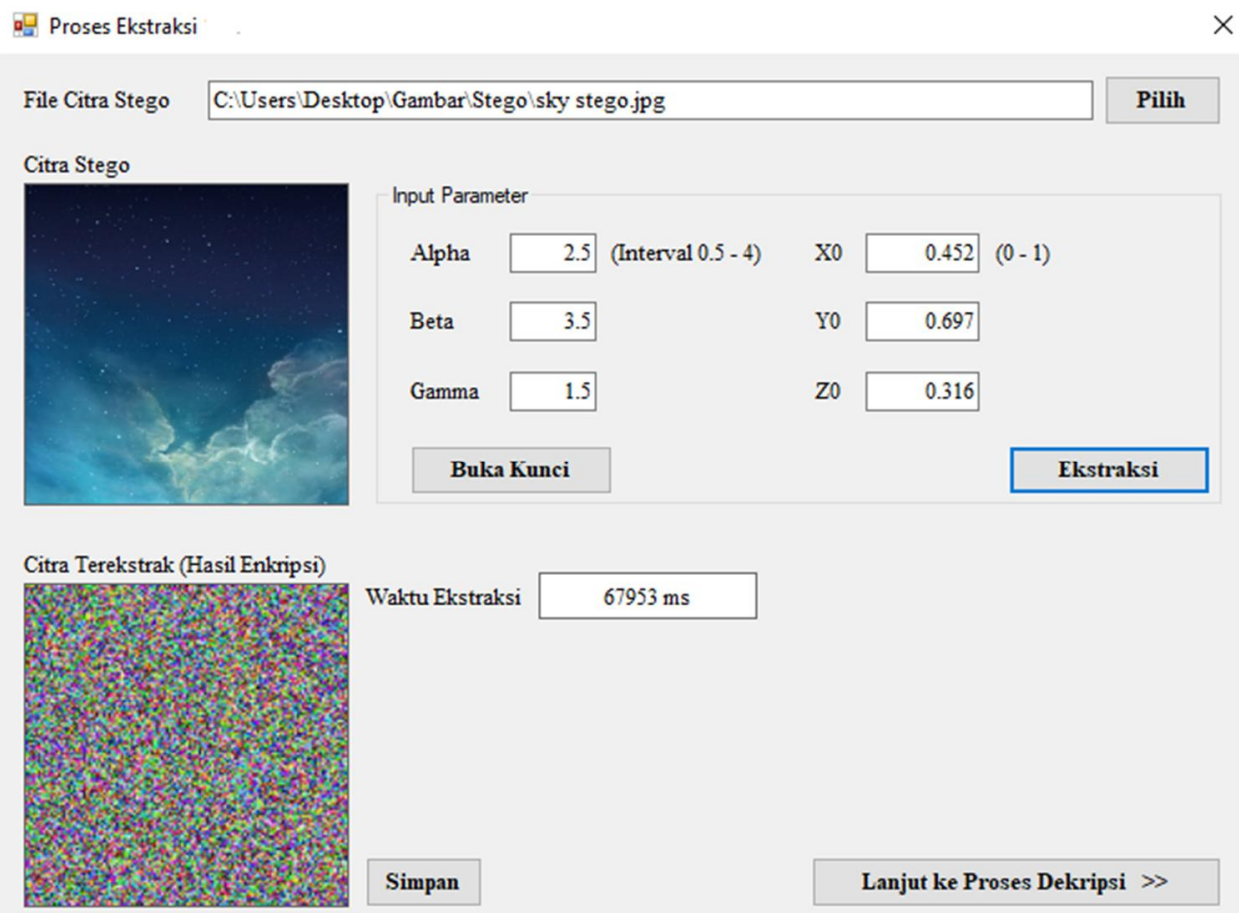

Gambar 6. Tampilan Form Proses Ekstraksi Setelah Citra Enkripsi Terekstrak 
Proses dekripsi dengan menggunakan metode Modified Serpent ini dapat dijalankan setelah proses ekstraksi dilakukan dengan mengklik tombol'Lanjut ke Proses Dekripsi' pada form Proses Ekstraksi sehingga sistem akan menampilkan form Proses Dekripsi seperti terlihat pada Gambar 7. berikut:

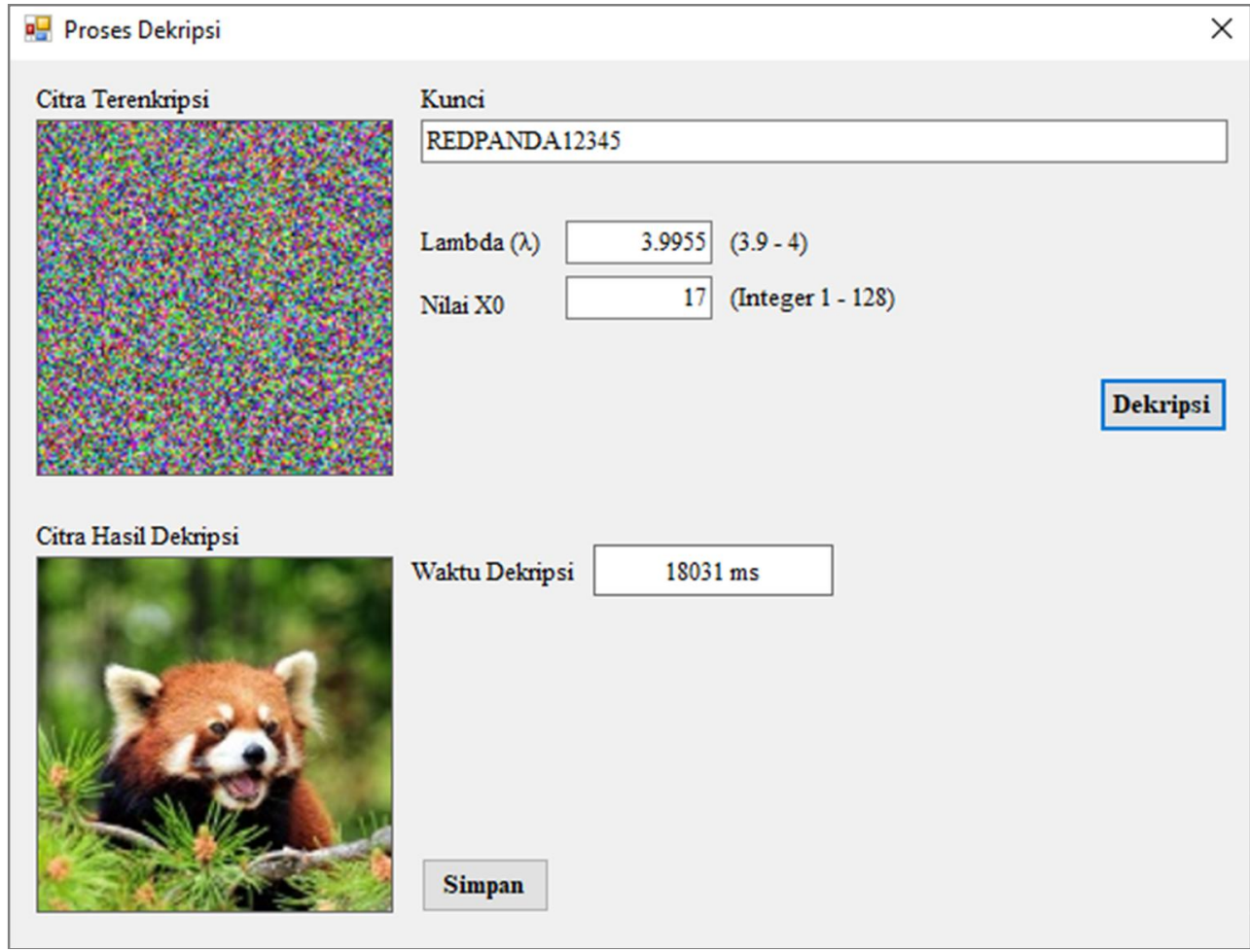

Gambar 7. Tampilan Form Proses Dekripsi Setelah Citra di Dekripsi

\subsection{Pembahasan}

Untuk memastikan bahwa perangkat lunak telah memenuhi kebutuhan dan tujuan yang diharapkan, maka dilakukan pengujian yang terbagi atas 2 (dua) bagian, yaitu pengujian waktu dan pengujian kualitas.

\subsubsection{Pengujian Waktu}

Dilakukan beberapa pengujian mengunakan citra pesan RGB berukuran 100 x 100 dan 200 x 200 dengan jenis citra yang sama. Mengubah nilai kunci dengan panjang karakter yang berbeda, menggunakan huruf kecil, besar, simbol, angka secara keseluruhan dan kombinasi diantaranya. Rincian hasil pengujian tersebut dapat dilihat pada Tabel 1 berikut.

Tabel 1. Hasil Pengujian Waktu Dengan Mengubah Nilai Kunci pada Citra 100 x 100 dan

\begin{tabular}{|c|c|c|c|c|c|c|c|}
\hline Citra Rahasia & Kunci & $\lambda$ & $\mathrm{X} 0$ & $\begin{array}{c}\text { Waktu } \\
\text { Enkripsi } \\
(100 x 100)\end{array}$ & $\begin{array}{c}\text { Waktu } \\
\text { Dekripsi } \\
(100 x 100)\end{array}$ & $\begin{array}{c}\text { Waktu } \\
\text { Enkripsi } \\
(200 x 200)\end{array}$ & $\begin{array}{c}\text { Waktu } \\
\text { Dekripsi } \\
(200 \times 200)\end{array}$ \\
\hline \multirow{6}{*}{ cat.jpg } & test & 3.9011 & 8 & $15140 \mathrm{~ms}$ & $5031 \mathrm{~ms}$ & $83813 \mathrm{~ms}$ & $24156 \mathrm{~ms}$ \\
\hline & testtesttest & 3.9011 & 8 & $14406 \mathrm{~ms}$ & $5031 \mathrm{~ms}$ & $83718 \mathrm{~ms}$ & $24063 \mathrm{~ms}$ \\
\hline & testtesttesttesttest & 3.9011 & 8 & $15188 \mathrm{~ms}$ & $5031 \mathrm{~ms}$ & $81344 \mathrm{~ms}$ & $23937 \mathrm{~ms}$ \\
\hline & $\begin{array}{l}\text { testtesttesttesttesttes } \\
\text { ttest }\end{array}$ & 3.9011 & 8 & $15172 \mathrm{~ms}$ & $5079 \mathrm{~ms}$ & $84438 \mathrm{~ms}$ & $25344 \mathrm{~ms}$ \\
\hline & 1234 & 3.9011 & 8 & $15766 \mathrm{~ms}$ & $5250 \mathrm{~ms}$ & $82578 \mathrm{~ms}$ & $23922 \mathrm{~ms}$ \\
\hline & 123456789012 & 3.9011 & 8 & $14937 \mathrm{~ms}$ & $5234 \mathrm{~ms}$ & $82360 \mathrm{~ms}$ & $23969 \mathrm{~ms}$ \\
\hline
\end{tabular}

Allwin, et., al [Pengamanan Citra Dengan Kombinasi Modified Serpent Dan IWT Dengan Modified Logistic 
Jatisi

ISSN 2407-4322

Vol. 8, No. 3, September 2021, Hal. 1090-1104 E- ISSN 2503-2933 1097

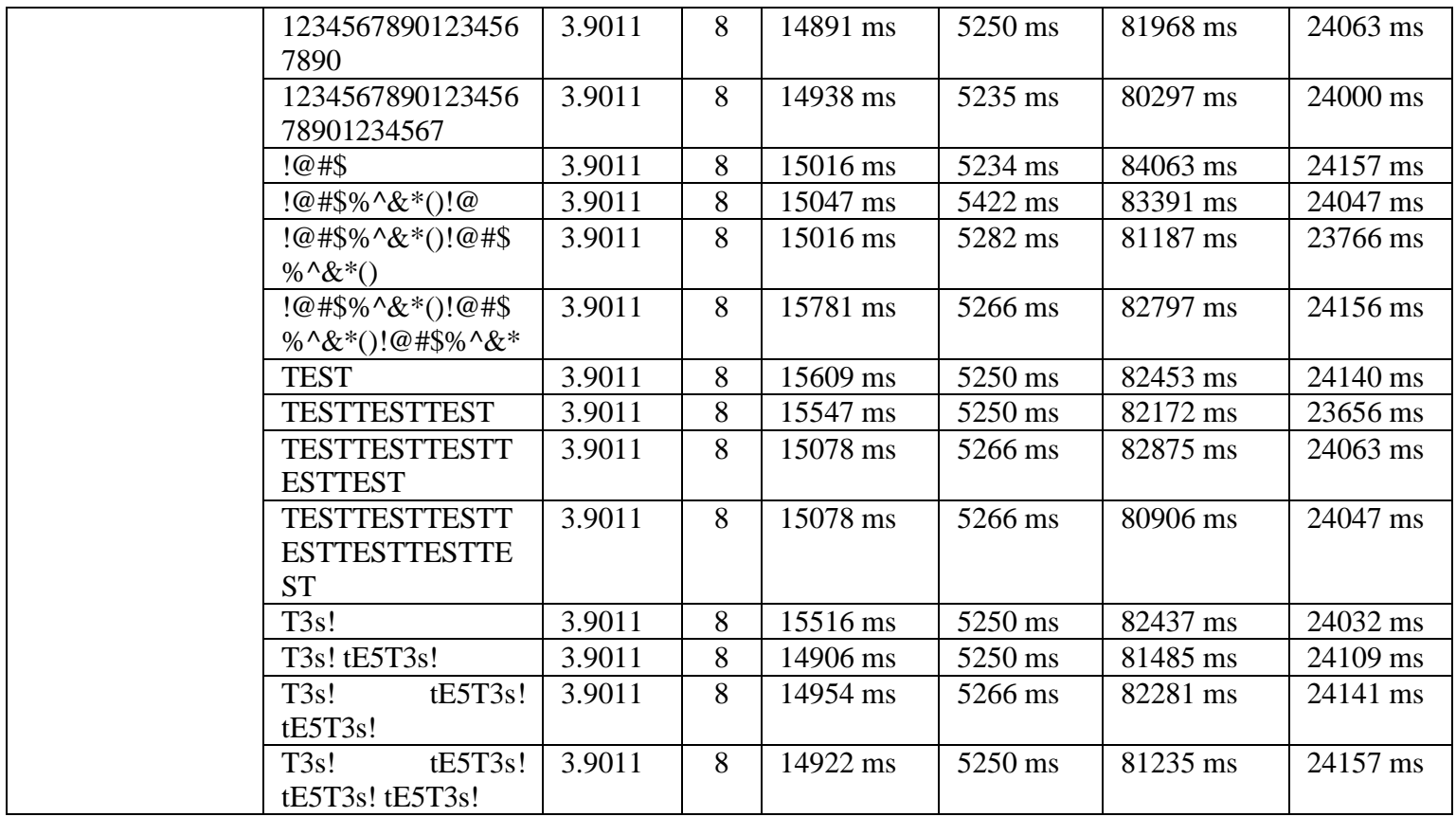

Pengujian waktu berikutnya dengan menggunakan citra dengan ukuran dan file yang sama. Pada pengujian ini hanya dilakukan perubahan nilai parameter lambda $(\lambda)$ dari nilai terkecil hingga terbesar dengan rentang $3.9>\lambda>4$. Untuk rincian hasil pengujian tersebut dapat dilihat pada Tabel 2. berikut.

Tabel 2. Hasil Pengujian Waktu Dengan Mengubah Nilai Parameter Lambda pada Citra $100 \times 100$ dan $200 \times 200$

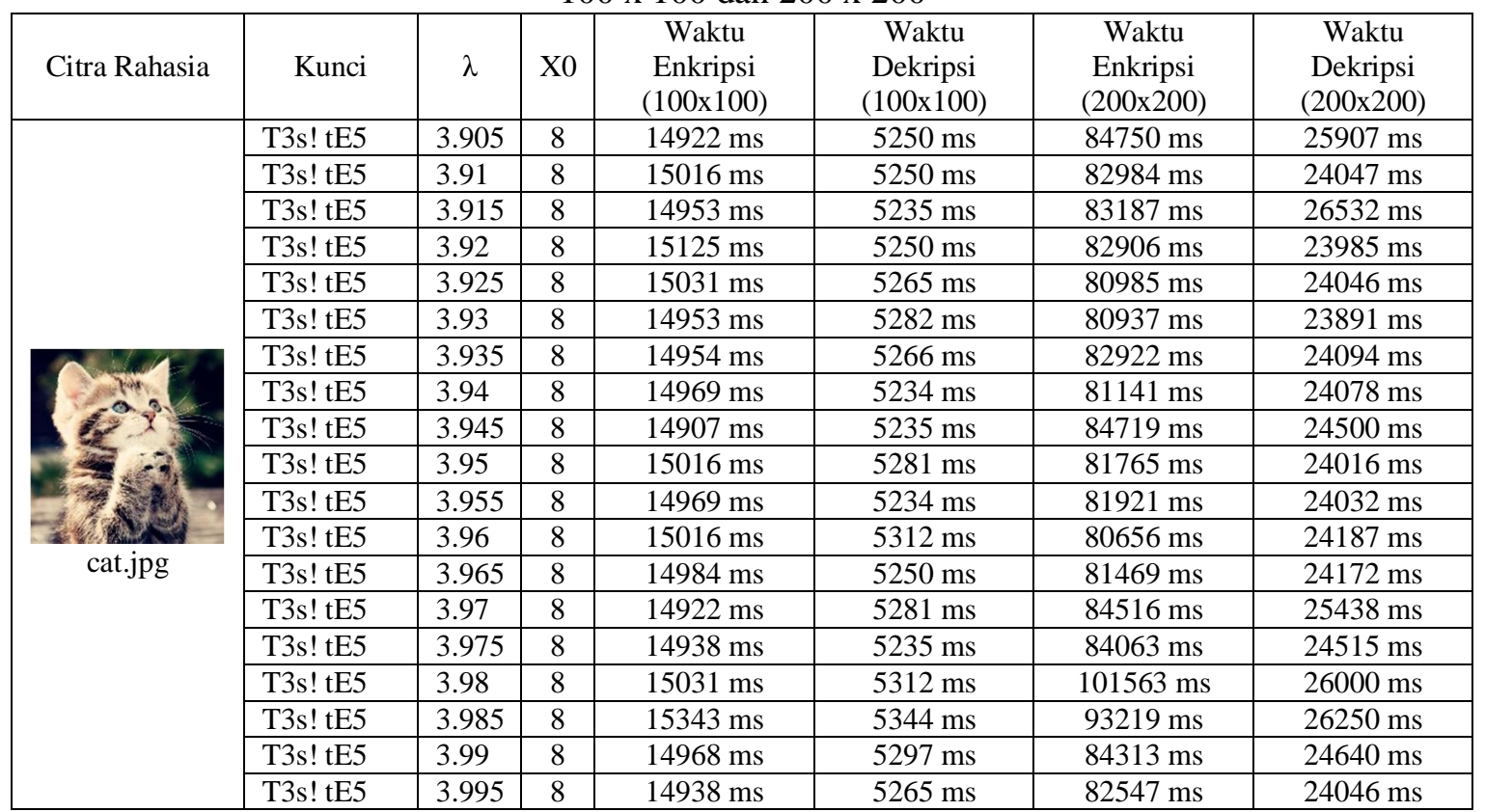

Allwin, et., al [Pengamanan Citra Dengan Kombinasi Modified Serpent Dan IWT Dengan Modified Logistic Chaotic Map] 
Pengujian waktu berikutnya dengan hanya mengubah nilai parameter $\mathrm{x} 0$ menggunakan citra yang sama pada pengujian sebelumnya. Rincian hasil pengujian dapat dilihat pada Tabel 3. berikut.

Tabel 3. Hasil Pengujian Waktu Dengan Mengubah Nilai Parameter X0 pada Citra 100 x 100 dan $200 \times 200$

\begin{tabular}{|c|c|c|c|c|c|c|c|}
\hline Citra Rahasia & Kunci & $\lambda$ & X0 & $\begin{array}{c}\text { Waktu } \\
\text { Enkripsi } \\
(100 x 100)\end{array}$ & $\begin{array}{c}\text { Waktu } \\
\text { Dekripsi } \\
(100 \times 100)\end{array}$ & $\begin{array}{c}\text { Waktu } \\
\text { Enkripsi } \\
(200 \times 200)\end{array}$ & $\begin{array}{c}\text { Waktu } \\
\text { Dekripsi } \\
(200 \times 200)\end{array}$ \\
\hline & T3s! tE5 & 3.9011 & 1 & $15187 \mathrm{~ms}$ & $5281 \mathrm{~ms}$ & $88594 \mathrm{~ms}$ & $24735 \mathrm{~ms}$ \\
\hline & T3s! tE5 & 3.9011 & 11 & $15125 \mathrm{~ms}$ & $5281 \mathrm{~ms}$ & $83656 \mathrm{~ms}$ & $24109 \mathrm{~ms}$ \\
\hline & T3s! tE5 & 3.9011 & 21 & $15016 \mathrm{~ms}$ & $5265 \mathrm{~ms}$ & $83015 \mathrm{~ms}$ & $24078 \mathrm{~ms}$ \\
\hline & T3s! tE5 & 3.9011 & 31 & $15094 \mathrm{~ms}$ & $5281 \mathrm{~ms}$ & $82891 \mathrm{~ms}$ & $24109 \mathrm{~ms}$ \\
\hline & T3s! tE5 & 3.9011 & 51 & $15031 \mathrm{~ms}$ & $5250 \mathrm{~ms}$ & $80907 \mathrm{~ms}$ & $24094 \mathrm{~ms}$ \\
\hline & T3s! tE5 & 3.9011 & 61 & $15015 \mathrm{~ms}$ & $5265 \mathrm{~ms}$ & $83547 \mathrm{~ms}$ & $24031 \mathrm{~ms}$ \\
\hline & T3s! tE5 & 3.9011 & 71 & $14985 \mathrm{~ms}$ & $5281 \mathrm{~ms}$ & $84766 \mathrm{~ms}$ & $24125 \mathrm{~ms}$ \\
\hline & T3s! tE5 & 3.9011 & 81 & $15047 \mathrm{~ms}$ & $5282 \mathrm{~ms}$ & $83687 \mathrm{~ms}$ & $24218 \mathrm{~ms}$ \\
\hline & T3s! tE5 & 3.9011 & 91 & $14984 \mathrm{~ms}$ & $5406 \mathrm{~ms}$ & $83703 \mathrm{~ms}$ & $24235 \mathrm{~ms}$ \\
\hline & T3s! tE5 & 3.9011 & 128 & $15203 \mathrm{~ms}$ & $5265 \mathrm{~ms}$ & $83422 \mathrm{~ms}$ & $23969 \mathrm{~ms}$ \\
\hline
\end{tabular}

Pengujian waktu berikut menggunakan jenis citra yang berbeda-beda dengan ukuran 100 x 100 dan 200 x 200. Kunci dan parameter yang dimasukan bernilai tetap untuk setiap citra yang diuji. Rincian hasil pengujian tersebut dapat dilihat pada Tabel 4. berikut.

Tabel 4. Hasil Pengujian Waktu Menggunakan Citra yang Berbeda Dengan Ukuran 100 x 100 dan $200 \times 200$

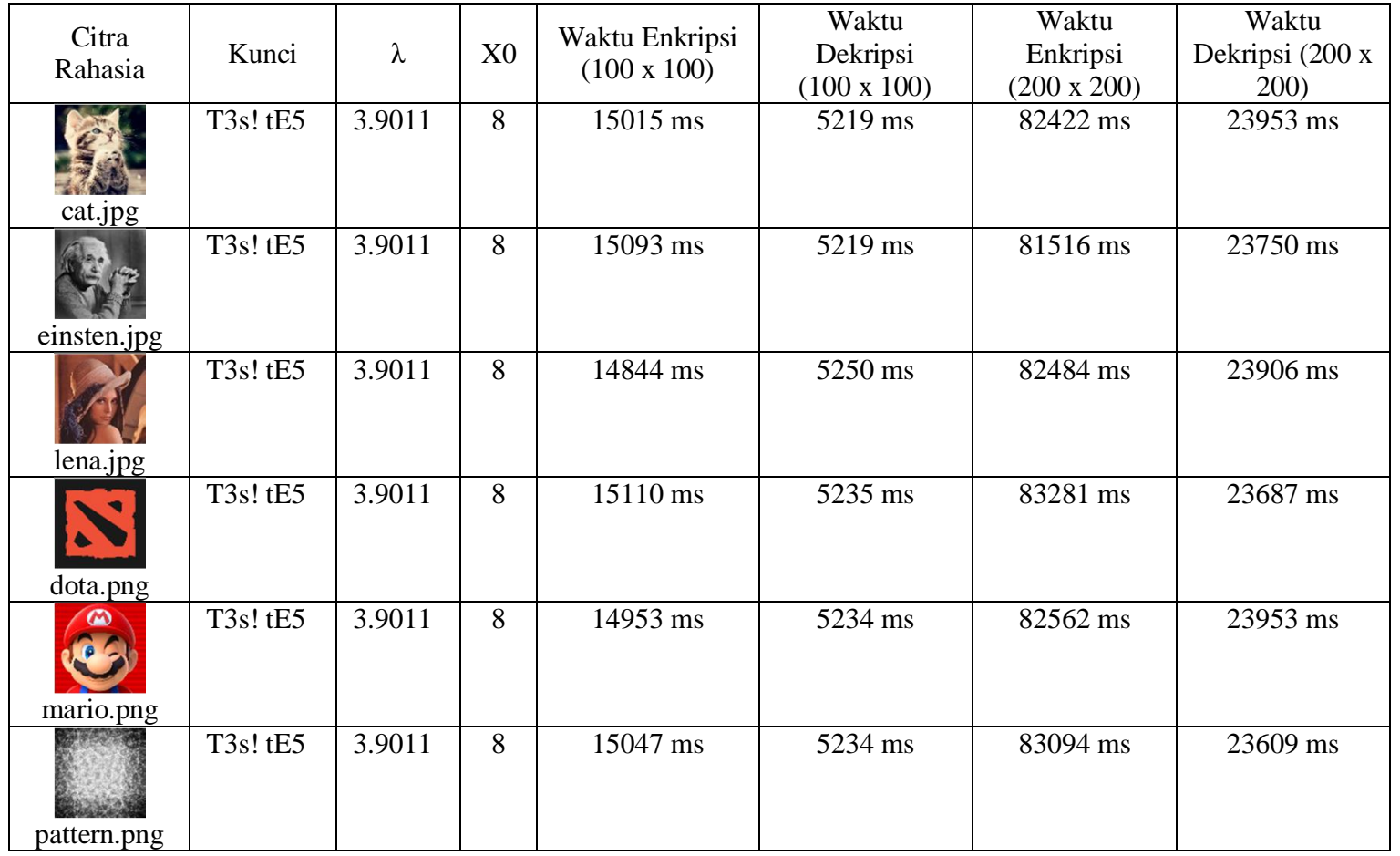

Allwin, et., al [Pengamanan Citra Dengan Kombinasi Modified Serpent Dan IWT Dengan Modified Logistic Chaotic Map] 
Jatisi

ISSN 2407-4322

Vol. 8, No. 3, September 2021, Hal. 1090-1104 E- ISSN 2503-2933 1099

\begin{tabular}{|c|l|l|l|l|l|c|c|}
\hline & T3s! tE5 & 3.9011 & 8 & $14828 \mathrm{~ms}$ & $5218 \mathrm{~ms}$ & $82843 \mathrm{~ms}$ & $23828 \mathrm{~ms}$ \\
\hline $\begin{array}{c}\text { pepper.bmp } \\
\text { sailboat.bmp }\end{array}$ & & & & & & & \\
\hline
\end{tabular}

Berdasarkan hasil pengujian waktu diatas, dapat diperoleh beberapa informasi berikut:

1. Perubahan nilai kunci dan parameter yang digunakan tidak berpengaruh terhadap kecepatan waktu enkripsi dan dekripsi, terbukti bahwa untuk setiap nilai dari kunci maupun parameter yang diubah berapa pun tidak mepengaruhi waktu secara signifikan.

2. Kecepatan enkripsi dan dekripsi hanya bergantung pada ukuran citra rahasia.

3. Waktu dekripsi jauh lebih cepat daripada waktu enkripsi sehingga metode Modified Serpent cocok untuk diterapkan secara praktikal, karena proses dekripsi biasanya dilakukan pada perangkat dengan sumber daya terbatas dan memadai.

\subsubsection{Pengujian Kualitas}

Dilakukan beberapa pengujian dengan menggunakan citra sampul RGB berukuran $512 \mathrm{x}$ 512 piksel dan citra pesan yang telah terenkripsi dengan ukuran $80 \times 80,100 \times 100$ dan $128 \times$ 128. Pada pengujian ini dilakukan perubahan nilai untuk setiap parameter dengan rentang tertentu untuk menguji kualitas citra setelah disisip citra pesan. Untuk rincian pengujian kualitas dengan citra pesan 80 × 80 dapat dilihat pada Tabel 5. berikut.

Tabel 5. Hasil Pengujian Kualitas Dengan Perubahan Nilai Parameter Terhadap Citra Pesan $80 \times 80$

\begin{tabular}{|c|c|c|c|c|c|c|c|c|}
\hline $\begin{array}{c}\text { Ukuran } \\
\text { Citra Pesan }\end{array}$ & X0 & Y0 & Z0 & $\alpha$ & $\beta$ & $\gamma$ & $\begin{array}{c}\text { Nilai } \\
\text { MSE }\end{array}$ & $\begin{array}{c}\text { Nilai PSNR } \\
(\mathrm{dB})\end{array}$ \\
\hline $80 \times 80$ & 0.111 & 0.111 & 0.111 & 0.5 & 0.5 & 0.5 & 0.8938 & 48.6184 \\
\hline $80 \times 80$ & 0.111 & 0.111 & 0.111 & $\mathbf{1 . 5}$ & 0.5 & 0.5 & 3.59829 & 42.56984 \\
\hline $80 \times 80$ & 0.111 & 0.111 & 0.111 & $\mathbf{2 . 5}$ & 0.5 & 0.5 & 3.8507 & 43.23815 \\
\hline $80 \times 80$ & 0.111 & 0.111 & 0.111 & $\mathbf{3 . 5}$ & 0.5 & 0.5 & 2.74515 & 43.74514 \\
\hline $80 \times 80$ & 0.111 & 0.111 & 0.111 & $\mathbf{4}$ & 0.5 & 0.5 & 2.53992 & 44.826 \\
\hline $80 \times 80$ & 0.111 & 0.111 & 0.111 & 0.5 & $\mathbf{1 . 5}$ & 0.5 & 2.98744 & 43.37781 \\
\hline $80 \times 80$ & 0.111 & 0.111 & 0.111 & 0.5 & $\mathbf{2 . 5}$ & 0.5 & 2.90369 & 43.5013 \\
\hline $80 \times 80$ & 0.111 & 0.111 & 0.111 & 0.5 & $\mathbf{3 . 5}$ & 0.5 & 2.41941 & 44.29371 \\
\hline $80 \times 80$ & 0.111 & 0.111 & 0.111 & 0.5 & $\mathbf{4}$ & 0.5 & 2.86312 & 43.56241 \\
\hline $80 \times 80$ & 0.111 & 0.111 & 0.111 & 0.5 & 0.5 & $\mathbf{1 . 5}$ & 3.14798 & 43.15048 \\
\hline $80 \times 80$ & 0.111 & 0.111 & 0.111 & 0.5 & 0.5 & $\mathbf{2 . 5}$ & 2.40865 & 44.31307 \\
\hline $80 \times 80$ & 0.111 & 0.111 & 0.111 & 0.5 & 0.5 & $\mathbf{3 . 5}$ & 2.2877 & 45.5848 \\
\hline $80 \times 80$ & 0.111 & 0.111 & 0.111 & 0.5 & 0.5 & $\mathbf{4}$ & 3.27354 & 42.98063 \\
\hline $80 \times 80$ & $\mathbf{0 . 2 2 2}$ & 0.111 & 0.111 & 0.5 & 0.5 & 0.5 & 2.59747 & 43.9853 \\
\hline $80 \times 80$ & $\mathbf{0 . 3 3 3}$ & 0.111 & 0.111 & 0.5 & 0.5 & 0.5 & 2.82471 & 43.62106 \\
\hline $80 \times 80$ & $\mathbf{0 . 4 4 4}$ & 0.111 & 0.111 & 0.5 & 0.5 & 0.5 & 2.82685 & 43.61778 \\
\hline $80 \times 80$ & $\mathbf{0 . 5 5 5}$ & 0.111 & 0.111 & 0.5 & 0.5 & 0.5 & 3.8083 & 43.24413 \\
\hline $80 \times 80$ & $\mathbf{0 . 6 6 6}$ & 0.111 & 0.111 & 0.5 & 0.5 & 0.5 & 2.57161 & 44.2875 \\
\hline $80 \times 80$ & $\mathbf{0 . 7 7 7}$ & 0.111 & 0.111 & 0.5 & 0.5 & 0.5 & 2.38375 & 44.3582 \\
\hline $80 \times 80$ & $\mathbf{0 . 8 8 8}$ & 0.111 & 0.111 & 0.5 & 0.5 & 0.5 & 2.62174 & 43.94491 \\
\hline $80 \times 80$ & $\mathbf{0 . 9 9 9}$ & 0.111 & 0.111 & 0.5 & 0.5 & 0.5 & 2.99974 & 43.35997 \\
\hline
\end{tabular}

Allwin, et., al [Pengamanan Citra Dengan Kombinasi Modified Serpent Dan IWT Dengan Modified Logistic Chaotic Map] 


\begin{tabular}{|c|c|c|c|c|c|c|c|c|}
\hline $80 \times 80$ & 0.111 & $\mathbf{0 . 2 2 2}$ & 0.111 & 0.5 & 0.5 & 0.5 & 3.2233 & 43.478 \\
\hline $80 \times 80$ & 0.111 & $\mathbf{0 . 3 3 3}$ & 0.111 & 0.5 & 0.5 & 0.5 & 2.65172 & 43.89553 \\
\hline $80 \times 80$ & 0.111 & $\mathbf{0 . 4 4 4}$ & 0.111 & 0.5 & 0.5 & 0.5 & 2.95097 & 43.43116 \\
\hline $80 \times 80$ & 0.111 & $\mathbf{0 . 5 5 5}$ & 0.111 & 0.5 & 0.5 & 0.5 & 2.97843 & 43.39093 \\
\hline $80 \times 80$ & 0.111 & $\mathbf{0 . 6 6 6}$ & 0.111 & 0.5 & 0.5 & 0.5 & 2.68814 & 43.83628 \\
\hline $80 \times 80$ & 0.111 & $\mathbf{0 . 7 7 7}$ & 0.111 & 0.5 & 0.5 & 0.5 & 2.83247 & 43.60915 \\
\hline $80 \times 80$ & 0.111 & $\mathbf{0 . 8 8 8}$ & 0.111 & 0.5 & 0.5 & 0.5 & 2.71501 & 43.79309 \\
\hline $80 \times 80$ & 0.111 & $\mathbf{0 . 9 9 9}$ & 0.111 & 0.5 & 0.5 & 0.5 & 2.48116 & 44.18426 \\
\hline $80 \times 80$ & 0.111 & 0.111 & $\mathbf{0 . 2 2 2}$ & 0.5 & 0.5 & 0.5 & 2.38417 & 44.35743 \\
\hline $80 \times 80$ & 0.111 & 0.111 & $\mathbf{0 . 3 3 3}$ & 0.5 & 0.5 & 0.5 & 2.84679 & 43.58725 \\
\hline $80 \times 80$ & 0.111 & 0.111 & $\mathbf{0 . 4 4 4}$ & 0.5 & 0.5 & 0.5 & 2.56189 & 44.452 \\
\hline $80 \times 80$ & 0.111 & 0.111 & $\mathbf{0 . 5 5 5}$ & 0.5 & 0.5 & 0.5 & 3.86143 & 42.26332 \\
\hline $80 \times 80$ & 0.111 & 0.111 & $\mathbf{0 . 6 6 6}$ & 0.5 & 0.5 & 0.5 & 2.71167 & 43.79844 \\
\hline $80 \times 80$ & 0.111 & 0.111 & $\mathbf{0 . 7 7 7}$ & 0.5 & 0.5 & 0.5 & 2.16908 & 44.76805 \\
\hline $80 \times 80$ & 0.111 & 0.111 & $\mathbf{0 . 8 8 8}$ & 0.5 & 0.5 & 0.5 & 2.46111 & 44.21949 \\
\hline $80 \times 80$ & 0.111 & 0.111 & $\mathbf{0 . 9 9 9}$ & 0.5 & 0.5 & 0.5 & 2.18413 & 44.73802 \\
\hline
\end{tabular}
6. berikut.

Untuk rincian pengujian kualitas dengan citra pesan 100 x 100 dapat dilihat pada Tabel

Tabel 6. Hasil Pengujian Kualitas Dengan Perubahan Nilai Parameter Terhadap Citra Pesan $100 \times 100$

\begin{tabular}{|c|c|c|c|c|c|c|c|c|}
\hline $\begin{array}{c}\text { Ukuran } \\
\text { Citra Pesan }\end{array}$ & X0 & Y0 & Z0 & $\alpha$ & $\beta$ & $\gamma$ & $\begin{array}{c}\text { Nilai } \\
\text { MSE }\end{array}$ & $\begin{array}{c}\text { Nilai PSNR } \\
(\mathrm{dB})\end{array}$ \\
\hline $100 \times 100$ & 0.111 & 0.111 & 0.111 & 0.5 & 0.5 & 0.5 & 0.89428 & 48.61607 \\
\hline $100 \times 100$ & 0.111 & 0.111 & 0.111 & $\mathbf{1 . 5}$ & 0.5 & 0.5 & 4.25159 & 41.84529 \\
\hline $100 \times 100$ & 0.111 & 0.111 & 0.111 & $\mathbf{2 . 5}$ & 0.5 & 0.5 & 4.23762 & 41.85958 \\
\hline $100 \times 100$ & 0.111 & 0.111 & 0.111 & $\mathbf{3 . 5}$ & 0.5 & 0.5 & 3.84877 & 42.27758 \\
\hline $100 \times 100$ & 0.111 & 0.111 & 0.111 & $\mathbf{4}$ & 0.5 & 0.5 & 3.43427 & 42.77246 \\
\hline $100 \times 100$ & 0.111 & 0.111 & 0.111 & 0.5 & $\mathbf{1 . 5}$ & 0.5 & 3.56347 & 42.61207 \\
\hline $100 \times 100$ & 0.111 & 0.111 & 0.111 & 0.5 & $\mathbf{2 . 5}$ & 0.5 & 3.83681 & 42.2911 \\
\hline $100 \times 100$ & 0.111 & 0.111 & 0.111 & 0.5 & $\mathbf{3 . 5}$ & 0.5 & 3.79082 & 42.34347 \\
\hline $100 \times 100$ & 0.111 & 0.111 & 0.111 & 0.5 & $\mathbf{4}$ & 0.5 & 3.53272 & 42.64971 \\
\hline $100 \times 100$ & 0.111 & 0.111 & 0.111 & 0.5 & 0.5 & $\mathbf{1 . 5}$ & 4.2969 & 42.7809 \\
\hline $100 \times 100$ & 0.111 & 0.111 & 0.111 & 0.5 & 0.5 & $\mathbf{2 . 5}$ & 3.75539 & 42.38425 \\
\hline $100 \times 100$ & 0.111 & 0.111 & 0.111 & 0.5 & 0.5 & $\mathbf{3 . 5}$ & 3.6958 & 42.45372 \\
\hline $100 \times 100$ & 0.111 & 0.111 & 0.111 & 0.5 & 0.5 & $\mathbf{4}$ & 4.16406 & 41.93563 \\
\hline $100 \times 100$ & $\mathbf{0 . 2 2 2}$ & 0.111 & 0.111 & 0.5 & 0.5 & 0.5 & 3.9742 & 43.2208 \\
\hline $100 \times 100$ & $\mathbf{0 . 3 3 3}$ & 0.111 & 0.111 & 0.5 & 0.5 & 0.5 & 3.22202 & 43.4952 \\
\hline $100 \times 100$ & $\mathbf{0 . 4 4 4}$ & 0.111 & 0.111 & 0.5 & 0.5 & 0.5 & 3.61784 & 42.54631 \\
\hline $100 \times 100$ & $\mathbf{0 . 5 5 5}$ & 0.111 & 0.111 & 0.5 & 0.5 & 0.5 & 4.38686 & 41.70927 \\
\hline $100 \times 100$ & $\mathbf{0 . 6 6 6}$ & 0.111 & 0.111 & 0.5 & 0.5 & 0.5 & 3.88301 & 42.23912 \\
\hline $100 \times 100$ & $\mathbf{0 . 7 7 7}$ & 0.111 & 0.111 & 0.5 & 0.5 & 0.5 & 3.51094 & 42.67657 \\
\hline $100 \times 100$ & $\mathbf{0 . 8 8 8}$ & 0.111 & 0.111 & 0.5 & 0.5 & 0.5 & 2.80841 & 43.6462 \\
\hline $100 \times 100$ & $\mathbf{0 . 9 9 9}$ & 0.111 & 0.111 & 0.5 & 0.5 & 0.5 & 4.388 & 42.10599 \\
\hline $100 \times 100$ & 0.111 & $\mathbf{0 . 2 2 2}$ & 0.111 & 0.5 & 0.5 & 0.5 & 4.71 & 42.10943 \\
\hline $100 \times 100$ & 0.111 & $\mathbf{0 . 3 3 3}$ & 0.111 & 0.5 & 0.5 & 0.5 & 3.89117 & 42.23 \\
\hline $100 \times 100$ & 0.111 & $\mathbf{0 . 4 4 4}$ & 0.111 & 0.5 & 0.5 & 0.5 & 4.69607 & 41.346 \\
\hline
\end{tabular}

Allwin, et., al [Pengamanan Citra Dengan Kombinasi Modified Serpent Dan IWT Dengan Modified Logistic 
Jatisi

ISSN 2407-4322

Vol. 8, No. 3, September 2021, Hal. 1090-1104 E- ISSN 2503-2933 1101

\begin{tabular}{|l|l|l|l|l|l|l|l|l|}
\hline $100 \times 100$ & 0.111 & $\mathbf{0 . 5 5 5}$ & 0.111 & 0.5 & 0.5 & 0.5 & 4.56464 & 41.53674 \\
\hline $100 \times 100$ & 0.111 & $\mathbf{0 . 6 6 6}$ & 0.111 & 0.5 & 0.5 & 0.5 & 3.51422 & 42.67251 \\
\hline $100 \times 100$ & 0.111 & $\mathbf{0 . 7 7 7}$ & 0.111 & 0.5 & 0.5 & 0.5 & 3.85265 & 42.27321 \\
\hline $100 \times 100$ & 0.111 & $\mathbf{0 . 8 8 8}$ & 0.111 & 0.5 & 0.5 & 0.5 & 3.7205 & 42.42479 \\
\hline $100 \times 100$ & 0.111 & $\mathbf{0 . 9 9 9}$ & 0.111 & 0.5 & 0.5 & 0.5 & 3.8941 & 42.22673 \\
\hline $100 \times 100$ & 0.111 & 0.111 & $\mathbf{0 . 2 2 2}$ & 0.5 & 0.5 & 0.5 & 3.62027 & 42.54339 \\
\hline $100 \times 100$ & 0.111 & 0.111 & $\mathbf{0 . 3 3 3}$ & 0.5 & 0.5 & 0.5 & 4.56 & 42.10413 \\
\hline $100 \times 100$ & 0.111 & 0.111 & $\mathbf{0 . 4 4 4}$ & 0.5 & 0.5 & 0.5 & 4.11397 & 41.98819 \\
\hline $100 \times 100$ & 0.111 & 0.111 & $\mathbf{0 . 5 5 5}$ & 0.5 & 0.5 & 0.5 & 4.60054 & 41.50272 \\
\hline $100 \times 100$ & 0.111 & 0.111 & $\mathbf{0 . 6 6 6}$ & 0.5 & 0.5 & 0.5 & 4.2169 & 41.88087 \\
\hline $100 \times 100$ & 0.111 & 0.111 & $\mathbf{0 . 7 7 7}$ & 0.5 & 0.5 & 0.5 & 3.24374 & 43.2034 \\
\hline $100 \times 100$ & 0.111 & 0.111 & $\mathbf{0 . 8 8 8}$ & 0.5 & 0.5 & 0.5 & 3.86673 & 42.25737 \\
\hline $100 \times 100$ & 0.111 & 0.111 & $\mathbf{0 . 9 9 9}$ & 0.5 & 0.5 & 0.5 & 3.47899 & 42.71627 \\
\hline
\end{tabular}

7. berikut.

Untuk rincian pengujian kualitas dengan citra pesan 100 x 100 dapat dilihat pada Tabel

Tabel 7. Hasil Pengujian Kualitas Dengan Perubahan Nilai Parameter Terhadap Citra Pesan $128 \times 128$

\begin{tabular}{|c|c|c|c|c|c|c|c|c|}
\hline $\begin{array}{c}\text { Ukuran } \\
\text { Citra Pesan }\end{array}$ & $\mathrm{X} 0$ & $\mathrm{Y} 0$ & $\mathrm{Z} 0$ & $\alpha$ & $\beta$ & $\gamma$ & $\begin{array}{c}\text { Nilai } \\
\text { MSE }\end{array}$ & $\begin{array}{c}\text { Nilai PSNR } \\
(\mathrm{dB})\end{array}$ \\
\hline $128 \times 128$ & 0.111 & 0.111 & 0.111 & 0.5 & 0.5 & 0.5 & 0.89449 & 48.61505 \\
\hline $128 \times 128$ & 0.111 & 0.111 & 0.111 & $\mathbf{1 . 5}$ & 0.5 & 0.5 & 5.8849 & 40.43341 \\
\hline $128 \times 128$ & 0.111 & 0.111 & 0.111 & $\mathbf{2 . 5}$ & 0.5 & 0.5 & 5.96303 & 40.37613 \\
\hline $128 \times 128$ & 0.111 & 0.111 & 0.111 & $\mathbf{3 . 5}$ & 0.5 & 0.5 & 5.87743 & 40.43893 \\
\hline $128 \times 128$ & 0.111 & 0.111 & 0.111 & $\mathbf{4}$ & 0.5 & 0.5 & 6.14403 & 40.24627 \\
\hline $128 \times 128$ & 0.111 & 0.111 & 0.111 & 0.5 & $\mathbf{1 . 5}$ & 0.5 & 6.10711 & 40.27245 \\
\hline $128 \times 128$ & 0.111 & 0.111 & 0.111 & 0.5 & $\mathbf{2 . 5}$ & 0.5 & 5.86503 & 40.4481 \\
\hline $128 \times 128$ & 0.111 & 0.111 & 0.111 & 0.5 & $\mathbf{3 . 5}$ & 0.5 & 5.99949 & 40.34966 \\
\hline $128 \times 128$ & 0.111 & 0.111 & 0.111 & 0.5 & $\mathbf{4}$ & 0.5 & 5.61466 & 40.63757 \\
\hline $128 \times 128$ & 0.111 & 0.111 & 0.111 & 0.5 & 0.5 & $\mathbf{1 . 5}$ & 5.95012 & 40.38555 \\
\hline $128 \times 128$ & 0.111 & 0.111 & 0.111 & 0.5 & 0.5 & $\mathbf{2 . 5}$ & 5.9562 & 40.38111 \\
\hline $128 \times 128$ & 0.111 & 0.111 & 0.111 & 0.5 & 0.5 & $\mathbf{3 . 5}$ & 5.86135 & 40.45083 \\
\hline $128 \times 128$ & 0.111 & 0.111 & 0.111 & 0.5 & 0.5 & $\mathbf{4}$ & 5.50554 & 40.7228 \\
\hline $128 \times 128$ & $\mathbf{0 . 2 2 2}$ & 0.111 & 0.111 & 0.5 & 0.5 & 0.5 & 5.2534 & 41.11915 \\
\hline $128 \times 128$ & $\mathbf{0 . 3 3 3}$ & 0.111 & 0.111 & 0.5 & 0.5 & 0.5 & 4.99429 & 41.14607 \\
\hline $128 \times 128$ & $\mathbf{0 . 4 4 4}$ & 0.111 & 0.111 & 0.5 & 0.5 & 0.5 & 5.63242 & 40.62385 \\
\hline $128 \times 128$ & $\mathbf{0 . 5 5 5}$ & 0.111 & 0.111 & 0.5 & 0.5 & 0.5 & 5.60852 & 40.64232 \\
\hline $128 \times 128$ & $\mathbf{0 . 6 6 6}$ & 0.111 & 0.111 & 0.5 & 0.5 & 0.5 & 6.28603 & 40.14704 \\
\hline $128 \times 128$ & $\mathbf{0 . 7 7 7}$ & 0.111 & 0.111 & 0.5 & 0.5 & 0.5 & 5.20068 & 40.9702 \\
\hline $128 \times 128$ & $\mathbf{0 . 8 8 8}$ & 0.111 & 0.111 & 0.5 & 0.5 & 0.5 & 5.57488 & 40.66845 \\
\hline $128 \times 128$ & $\mathbf{0 . 9 9 9}$ & 0.111 & 0.111 & 0.5 & 0.5 & 0.5 & 5.78457 & 40.50809 \\
\hline $128 \times 128$ & 0.111 & $\mathbf{0 . 2 2 2}$ & 0.111 & 0.5 & 0.5 & 0.5 & 5.88828 & 40.43092 \\
\hline $128 \times 128$ & 0.111 & $\mathbf{0 . 3 3 3}$ & 0.111 & 0.5 & 0.5 & 0.5 & 6.78788 & 39.81346 \\
\hline $128 \times 128$ & 0.111 & $\mathbf{0 . 4 4 4}$ & 0.111 & 0.5 & 0.5 & 0.5 & 5.59839 & 40.65017 \\
\hline $128 \times 128$ & 0.111 & $\mathbf{0 . 5 5 5}$ & 0.111 & 0.5 & 0.5 & 0.5 & 5.50864 & 40.72036 \\
\hline $128 \times 128$ & 0.111 & $\mathbf{0 . 6 6 6}$ & 0.111 & 0.5 & 0.5 & 0.5 & 5.40202 & 40.80524 \\
\hline $128 \times 128$ & 0.111 & $\mathbf{0 . 7 7 7}$ & 0.111 & 0.5 & 0.5 & 0.5 & 5.49782 & 40.7289 \\
\hline
\end{tabular}

Allwin, et., al [Pengamanan Citra Dengan Kombinasi Modified Serpent Dan IWT Dengan Modified Logistic Chaotic Map] 


\begin{tabular}{|c|c|c|c|c|c|c|c|c|}
\hline $128 \times 128$ & 0.111 & $\mathbf{0 . 8 8 8}$ & 0.111 & 0.5 & 0.5 & 0.5 & 5.26006 & 40.9209 \\
\hline $128 \times 128$ & 0.111 & $\mathbf{0 . 9 9 9}$ & 0.111 & 0.5 & 0.5 & 0.5 & 5.4676 & 41.10068 \\
\hline $128 \times 128$ & 0.111 & 0.111 & $\mathbf{0 . 2 2 2}$ & 0.5 & 0.5 & 0.5 & 5.70839 & 40.56567 \\
\hline $128 \times 128$ & 0.111 & 0.111 & $\mathbf{0 . 3 3 3}$ & 0.5 & 0.5 & 0.5 & 5.6995 & 40.57244 \\
\hline $128 \times 128$ & 0.111 & 0.111 & $\mathbf{0 . 4 4 4}$ & 0.5 & 0.5 & 0.5 & 5.61572 & 40.63675 \\
\hline $128 \times 128$ & 0.111 & 0.111 & $\mathbf{0 . 5 5 5}$ & 0.5 & 0.5 & 0.5 & 5.27608 & 40.90769 \\
\hline $128 \times 128$ & 0.111 & 0.111 & $\mathbf{0 . 6 6 6}$ & 0.5 & 0.5 & 0.5 & 5.2418 & 40.936 \\
\hline $128 \times 128$ & 0.111 & 0.111 & $\mathbf{0 . 7 7 7}$ & 0.5 & 0.5 & 0.5 & 5.56557 & 40.67571 \\
\hline $128 \times 128$ & 0.111 & 0.111 & $\mathbf{0 . 8 8 8}$ & 0.5 & 0.5 & 0.5 & 6.19591 & 40.20975 \\
\hline $128 \times 128$ & 0.111 & 0.111 & $\mathbf{0 . 9 9 9}$ & 0.5 & 0.5 & 0.5 & 5.92876 & 40.40116 \\
\hline
\end{tabular}

Pengujian kualitas berikutnya yang dilakukan yaitu mengubah citra sampul yang digunakan, citra sampul berukuran 512 x 512. Lalu citra pesan yang digunakan akan tetap sama untuk setiap citra sampul yang diuji serta nilai dari parameter yang di input juga bernilai tetap. Pada pengujian tersebut dapat dilihat pada Tabel 8 . berikut.

Tabel 8. Hasil Pengujian Kualitas Menggunakan Citra Sampul Yang Berbeda Dengan Citra Pesan $128 \times 128$

\begin{tabular}{|c|c|c|c|c|c|c|c|c|c|}
\hline $\begin{array}{c}\text { Citra } \\
\text { Sampul }\end{array}$ & $\begin{array}{c}\text { Ukuran } \\
\text { Citra } \\
\text { Pesan }\end{array}$ & X0 & Y0 & $\mathrm{Z} 0$ & $\alpha$ & $\beta$ & $\gamma$ & $\begin{array}{l}\text { Nilai } \\
\text { MSE }\end{array}$ & $\begin{array}{l}\text { Nilai } \\
\text { PSNR } \\
\text { (dB) }\end{array}$ \\
\hline & $\begin{array}{c}128 \mathrm{x} \\
128\end{array}$ & 0.843 & 0.754 & 0.236 & 3 & 1.5 & 0.5 & 5.90369 & 40.41957 \\
\hline & $\begin{array}{c}128 \mathrm{x} \\
128\end{array}$ & 0.843 & 0.754 & 0.236 & 3 & 1.5 & 0.5 & 68.2031 & 29.79276 \\
\hline & $\begin{array}{c}128 \mathrm{x} \\
128\end{array}$ & 0.843 & 0.754 & 0.236 & 3 & 1.5 & 0.5 & 82.46058 & 28.96834 \\
\hline & $\begin{array}{c}128 \mathrm{x} \\
128\end{array}$ & 0.843 & 0.754 & 0.236 & 3 & 1.5 & 0.5 & 311.22984 & 23.19999 \\
\hline & $\begin{array}{c}128 \mathrm{x} \\
128\end{array}$ & 0.843 & 0.754 & 0.236 & 3 & 1.5 & 0.5 & 3.29898 & 42.94701 \\
\hline & $\begin{array}{c}128 \mathrm{x} \\
128\end{array}$ & 0.843 & 0.754 & 0.236 & 3 & 1.5 & 0.5 & 16.553 & 36.881 \\
\hline & $\begin{array}{c}128 \mathrm{x} \\
128\end{array}$ & 0.843 & 0.754 & 0.236 & 3 & 1.5 & 0.5 & 112.55881 & 27.61701 \\
\hline & $\begin{array}{c}128 \mathrm{x} \\
128\end{array}$ & 0.843 & 0.754 & 0.236 & 3 & 1.5 & 0.5 & 5.13725 & 41.235 \\
\hline
\end{tabular}

Berdasarkan hasil pengujian kualitas diatas, dapat diperoleh beberapa informasi berikut:

1. Semua nilai parameter $\mathrm{x} 0, \mathrm{y} 0, \mathrm{z} 0, \alpha, \beta, \gamma$ yang diberi nilai sama akan menghasilkan nilai MSE dan PSNR yang lebih baik dibandingkan dengan nilai parameter lainnya yang berubah atau tidak sama.

2. Perubahan nilai parameter yang digunakan tidak berpengaruh pada kualitas citra stego, terbukti bahwa nilai MSE pada citra 80 x 80 hanya berkisar antara 0.8938 sampai 3.86143 dan nilai PSNR antara 42.26332 sampai 48.6184 dB. Nilai MSE pada citra 100 x 100 hanya berkisar antara 0.89428 sampai 4.71 dan nilai PSNR antara 41.346 sampai $48.61607 \mathrm{~dB}$. 
Nilai MSE pada citra 128 x 128 hanya berkisar antara 0.89449 sampai 6.78788 dan nilai PSNR antara 39.81346 sampai $48.61505 \mathrm{~dB}$. Serta hampir keseluruhan kualitas citra stego yang dihasilkan relatif cukup baik dengan nilai PSNR > $40 \mathrm{~dB}$.

3. Kualitas citra stego hanya berpengaruh terhadap ukuran citra pesan, sehingga semakin besar ukuran citra pesan maka semakin buruk kualitas citra stego yang diperoleh.

4. Untuk beberapa kondisi dimana dengan menggunakan citra sampul yang berbeda masih terdapat beberapa hasil yang terbilang tidak cukup baik dikarenakan perbedaan warna antara citra sampul dan citra pesan yang digunakan.

\section{KESIMPULAN}

Berdasarkan hasil dari pengujian yang dilakukan terhadap Pengamanan Citra Warna Menggunakan Kriptografi Modified Serpent Dan Steganografi IWT Dengan Modified Logistic Chaotic Map diperoleh beberapa kesimpulan, yaitu perubahan nilai kunci dan parameter yang digunakan pada Modified Serpenttidak berpengaruh terhadap kecepatan waktu enkripsi dan dekripsi, terbukti bahwa untuk setiap nilai dari kunci maupun parameter yang diubah tidak mepengaruhi waktu secara signifikan. Serta kecepatan enkripsi dan dekripsi hanya bergantung pada ukuran citra rahasia. Selain itu, waktu dekripsi jauh lebih cepat daripada waktu enkripsi sehingga metode Modified Serpent cocok untuk diterapkan secara praktikal, karena proses dekripsi biasanya dilakukan pada perangkat dengan sumber daya terbatas dan memadai.Semua nilai parameter x0, y0, z0, $\alpha, \beta, \gamma$ dari algoritma Modified Logistic Chaotic Map yang diberi nilai sama akan menghasilkan nilai MSE dan PSNR yang lebih baik dibandingkan dengan nilai parameter lainnya yang berubah atau tidak sama. Lalu perbandingan antara perubahan nilai parameter yang digunakan tidak berpengaruh pada kualitas citra stego yang dihasilkan.

\section{SARAN}

Beberapa saran dari penulis yang ingin disampaikan mungkin berguna untuk pengembangan lebih lanjut pada perangkat lunak, sebagai berikut:

1. Perangkat lunak dapat dikembangkan lagi dengan membandingkan metode yang dibahas dengan metode lainnya yang sejenis sehingga dapat diketahui lebih lanjut kelebihan dan kelemahan dari metode yang digunakan.

2. Perangkat lunak ini dapat dikembangkan lagi sehingga dapat menyembunyikan file lainnya selain file citra, seperti file audio, file video, teks dan sebagainya.

3. Perangkat lunak dapat diekspansi lagi dengan menerapkan metode kriptografi lainnya yang lebih tangguh, seperti AES, DES, IDEA, dsb agar dapat mempertangguh keamanan dari data rahasia yang disembunyikan dalam citra digital.

\section{DAFTAR PUSTAKA}

[1] M. H. Taher, A. E. El_Deen and M. E. Abo-Elsoud, "Hardware Implementation Of The Serpent Block Cipher Using Fpga Technology," Journal Impact Factor, Vol. 5, No. 10, pp. 34-44, 2014.

[2] H. M. Elkamchouchi, A. E. Takieldeen and M. A. Shawky, "A Modified Serpent Based Algorithm for Image Encryption," National Radio Science Conference (NRSC 2018), pp. 1-

Allwin, et., al [Pengamanan Citra Dengan Kombinasi Modified Serpent Dan IWT Dengan Modified Logistic 
$10,2018$.

[3] T. Lestari, N. Nurmaesa and A. R. Mariana, "Aplikasi Steganografi Untuk Menyisipkan Pesan Dalam Media Image," Jurnal Sisfotek Global, Vol. 7, No. 2, pp. 22-26, 2017.

[4] S. Jayasudha, "Integer Wavelet Transform Based Steganographic Method Using Opa Algorithm," Research Inventy: International Journal Of Engineering and Science, Vol. 2, No. 4, pp. 31-35, 2013.

[5] A. Jan, S. A. Parah and B. A. Malik, "Logistic Map-Based Image Steganography Using Edge Detection," Springer Nature Singapore Pte Ltd, pp. 447-454, 2021.

[6] M. Ulker and B. Arslan, "A Novel Secure Model: Image Steganography with Logistic Map and Secret Key," IEEE, 2018.

[7] M. Y. Valandar, P. Ayubi and M. J. Barani, "A New Transform Domain Steganography Based On Modified Logistic Chaotic Map For Color Images," Journal of Information Security and Applications, pp. 1-10, 2017.

[8] B. W. Rauf, "Kombinasi Steganografi Bit Matching dan Kriptografi Playfair Cipher, Hill Cipher Dan Blowfish," Jurnal Teknologi Informasi, Vol. 4, No. 2, pp. 228-233, 2020.

[9] S. B. Kembaren, Suryadi and Triswanto, "Implementasi Algoritma Enkripsi Citra Digital Berbasis Chaos Menggunakan Fungsi Komposisi Logistic dan Gauss Iterated Map," Seminar Nasional Edusainstek FMIPA UNIMUS 2018, pp. 263-272, 2018.

[10] D. Darwis, Wamiliana and A. Junaidi, "Proses Pengamanan Data Menggunakan Kombinasi Metode Kriptografi Data Encryption Standard dan Steganografi and of File," Prosiding Seminar Nasional Metode Kuantitatif 2017, pp. 228-240, 2017. 